ISSN No. 0974-035X

An Indexed, Refereed \& Peer Reviewed Journal of Higher Education

Towards Excellence

UGC-HUMAN RESOURCE DEVELOPMENT CENTRE,

GUJARAT UNIVERSITY, AHMEDABAD, INDIA

\title{
REPRESENTATION OF SUPPRESSED WOMEN IN NEIL BISSOONDATH'S THE INNOCENCE OF AGE AND THE SOUL OF ALL GREAT DESIGNS
}

\section{Mr. Nirav Mehta}

Diasporic literature is a very broad term that includes all those literary works written by the authors outside their native country, but related to the native culture and background. It is a kind of psychological attempt to regain, which the writer has lost at the level of reality.

With the concept of Globalization, people have migrated for various purposes and result is that what was local has become global and the whole earth is identified as the global village. Therefore, diasporic discourse is mainly about the location of culture, search for identity and the quest for a home through self-discovery or self-realization. Neil Bissoondath, as a diasporic author, focuses on problem of identity, marginalization and suppression of women in his own way through criticism of Canadian Multiculturalism. Views of Neil Bissoondath on multiculturalism in Canada are much debated; in his literary work he makes and attempt to focus on the (multi)ethnic landscape of Canada today, straddling the emotive and receptive worlds of the protagonists. The concept of Multiculturalism greatly varies in terms of its deployment in individual national contexts.

Bissoondath's novel, The Innocence of Age, concerned with multiculturalism and its problems. It talks about multiculturalism in an allegorical way by taking recourse to the motif of house. $\mathrm{Mr}$. Simmons is the owner of the house who offers Daniel the task of renovating the house as per the wishes of the employer but it proves difficult because Daniel lacks inspiration to meet $\mathrm{Mr}$. Simmons' demands because the parts of the house refuse to become a good gestalt in his mind. To talk in a precise manner, the difficulty of renovation of Simmons' house also indicates that Canada's multicultural policy is in need of rethinking and reform. The house resists Daniel not only in terms of its gestalt but by its persistent silence. The silence of the house is closely connected to the silence of its (illegal) tenant Sita, 19 years old girl who happens to be the victim 
of human trafficking or 'Kabutarbazi'. The original name of Sita's country is not revealed by the author but from her description we realize that she is from a Caribbean country where food is precious than money. The author tried to depict her condition by mentioning that her father was killed by thieves and her sixteen years old younger sister is pregnant. She happens to be the elder one among five children in family so she has to migrate to Canada to remove their poverty. Sita has been dropped by a consultant in Mr. Leon's old house who never returned. Mr. Simmons abducts her passport and return-ticket and provides her some small work, which enables her to earn scanty money to have some food. Thus, she has been exploited financially as well as sexually by Mr. Simmons. Due to her illegal entry into Canada, she is unable to protest and nobody is a savior to send her away from this place to her home. Once she asked for help from Danny to recover her passport from Mr. Leon but got disappointed. While migrating to Canada, she had plenty of positive thoughts about the unknown country but realization of devastating facts about Canada and its people Sita feels disheartened with great disappointment and grief. She voices out:

“...Before I came here, I didn't know it had people like that in this country. Back home people always sayin' Canada rich-rich, it ain't have no poor people up there."1 (133)

When she immigrated to Canada, she dreamed about prosperity of the country but now she feels that even this country has poor people like other parts of the world. She craves for her home too much but she is in such a pathetic condition that neither she can get back to her home nor tell the real story to her family and also can't spend her life smoothly in unknown country. The fact is Danny is aware about Sita - 'a secret passion' of Simmons as Sal, the accountant calls it but he does not disclose anything to anyone up to last moment because he thinks it as a loyalty to the boss. One day, Sal who hates irregularities, inquires Danny about Sita because her name is not on payroll and still she performs plenty of duties like cleaning, sweeping of the buildings and rooms, then Danny avoids him by calling Sita as 'a charity case'. It sounds like Danny is also indirectly involving or associating himself into the conspiracy of Mr. Simmons. In fact, Danny is too much impressed by Mr. Leon Simmons and his success in business that he wishes to build his career in the same manner. Once Danny questions Sita about her exploitation and she replies with the theory of Simmons where reward is faithfulness or loyalty not money. The concern for Sita increases when Danny listens pain of Sita from adjoining room in Mr. Simmons' old 
heritage house while she is being sexually exploited. When Sita hits Mr. Leon with hammer twice or thrice which leads him to comma, Danny saved her life from police and takes her to safe place. There Sita is in a critical condition as she cannot go anywhere in Canada because she is alone and her journey leads her 'nowhere' and while returning to her home, she is not glad because she wondered what she would tell her family about her stay in Canada. At last, she departs to her home country (homeland) with some bad impression about Canada where she desired to immigrate.

Within the perspective of novel silence of Sita, involuntarily imposed on house, is less indicative of her cultural marginalization than of her marginalization as an individual. The inhumanity of Simmons consists not so much in his failure to acknowledge Sita's cultural identity but in his callous and cruel treatment of her as a human being.

Second novel The Soul of All Great Designs deals with Sue or Sumintra, the daughter of an Indian immigrant to Canada, who feels trapped or bewildered between Western Culture and Indian traditions. To overcome loneliness of teenage like other Canadian youth and experience some adventure in life, Sue falls in love with Alec, enjoys sensual pleasure but when time comes they both hesitate to accept the relationship in public.

Kelly, Sue's friend is the representative of Canadian youth, a carefree girl and wants to live life on her own choice but in case of Sumintra and Rima, Sumintra's friend representIndian girls in Canada who have to follow traditional Indian mindset as per wishes of their parents. Sumintra's mother is a typical Indian mother expecting her daughter to behave like a sincere girl who should possess good qualification whereas Sumintra had given up architecture for studying English Literature. Partially Rima and Sumintra, reflect Indian origin girls in Canada who have to suffer a lot in the name of family and community honor and have to pass their lives by repressing their dreams, under the constant restraints of their parents like a 'prisoned innocent'. The mother of Sumintra is so fearful that her daughter would become totally westernized so she does not permit her to go for party at Kelly's apartment after graduation by providing excuse of security. Despite unwillingness of Sue's parents, she decides to accept a job in accounting department of an architectural firm as recommended by Kelly. She has taken this decision to live her life in freedom and on the other side; she feels a sense of guilt when she becomes aware that her father had borrowed money from someone with interest rate to pay the fees of her university course and 
other expenses. To make her happy they lived a life of deprivation in their adopted country during transmission. When the matter comes to marry someone Sumintra desires to escape from unexpected meetings arranged for her to choose her future husband, because mostly they are not of her 'type'. For Sumintra, the whole question of 'type' is a complicated one as she merely wants adventures in the presence of man in her life.

Sumintra also feels neglected in Canada not only at personal but also at social level which is symbolically presented by the scene at dinner table wherein she has knife and fork in hands but has to eat Indian food and she thinks if she has to follow Indian tradition even in Canada then what is the need of 'fork' and 'knife'. When Alec and Sue meet on their first date, they hide lot of things from each other. Sue hides about Alec even to her parents. Though Kelly is Sue's best friend, she shares only favourable matter about him like only his name (which is not real) for Sue, it is another pair of eyes, after her parents who spy on her means her life has become a kind of film to watch or spectacle. The situation in which Sue has to suppress her ambition and dreams from the very beginning, which leads her to live life like a drifting boat. However, Kelly remarks that drifting boat does not always end up on some shore because sometimes it sinks at the bottom of sea, but Sue wants to be optimistic and she is searching for a place where she can be with her real self, not with an artificial personality "I'm looking for a place where I can be myself, just myself, all the time."2 (174)

To get more affection and focus once Sue shares all the real problems to Alec as she is facing in her life, but in different way by giving birth to her alter-ego in the name of her elder sister Sumintra. She informs Alec that her parents did not know about their relationship and they will not accept it, so they have to end their relationship. Kelly advises Sue to make the choice out of two - parents of Alec. However, Sue or Sumintra is fearful about the acceptance of Alec by her parents as a groom. Sue is ready to make her decision as her parents have made up their mind to marry her off to an aged Professor Motilal Mukherjee, a widower and son of Manohar's (Sue's father) mentor at engineering and a nuclear physicist which signifies a perfect Indian groom with high qualification and reputation although he has a ten year old daughter. The excuse provided by Sue's mother for this choice is that "Sumintra! you are running out of choice."2 (193) But for Sue, it is her parents who are running out of choice. After the disapproval from parents to spend her life with Alec, Sue has stolen her birth certificate, passport and other testimonials from the 
house, leaves it with hesitation. On the other side, Alec is perplexed to reveal his identity to Sue and accepting the relationship in public. He voices it out, "I'm saying that I can't do what you want to do. I have too much to lose."2 (216) It's shocking for Sue to listen this as she has lost almost everything - her parents, house, friend and now Alec. However, Alec unfolds everything about him to Sue with a complete truth about his personality and profession. But for Sue, it's an extreme sense of betrayal by the person whom she loves and is ready to leave everything for him. When Alec blames Sue for lying with her parents, her anger and sense of betrayal grows. She orders Alec to stop the car and runs out of car through the dark, deserted street. The fear of Alec that Sue might reveal his secrets to the world makes him murder Sue with car.

\section{Conclusion:}

The Innocence of Age within the perspective deals with Silence of Sita, involuntarily imposed on house, is less indicative of her cultural marginalization than of her marginalization as individual. This point is crucial for an understanding of text in terms of its treatment of cultural differences. Bissoondath with intermingling multiculturalism in the context of exploitation of an illegal immigrant Sita, presented the plight of women being suppressed by Man with power. Whereas another novel, The Soul of All Great Designs deals with the mental turbulence of Sue or Sumintra to accept Canadian Identity or Indian traditions and it resulted with loss of life of Sue due to suppression she faced throughout her life. 


\section{$\underline{\text { Reference }}$}

1 Bissoondath, Neil. The Innocence of Age. Canada: Penguin Books, 1992. Print

2 The Soul of All Great Designs. Canada: Cormorant Books Inc., 2008. Print

3 Nelson, Emmanuel S. Writers of The Indian Diaspora A Bio-Bibliographical Critical Sourcebook. Jaipur: Rawat Publications, Indian Reprint, 2010. Print

4 Bhabha, Homi K., Cultures In-Between, “Questions of Cultural Identity”, Ed. Stuart Hall and Paul Du Gay, London: SAGE, 1996. Print

5 New Diasporic Literature in a Post-ethnic Transcultural Canada by Igor Mavor Accessed on from http://myuminfo.umanitoba.ca/Documents/2142/MaverI.pdf Web

\section{Mr. Nirav Mehta}

Lecturer in English, Shri D N Institute of Business Administration, Anand.

$\&$

Research Scholar

Sardar Patel University,

Vallabh Vidyanagar.

Contact: (m) 9687573461

Email:niravmehta08@gmail.com 